THE MISSING COURSE 



\title{
THE MISSING COURSE Everything They Never Taught You about College Teaching
}

\author{
David Gooblar
}

\author{
III \\ III \\ Harvard University Press \\ Cambridge, Massachusetts, and London, England 2019
}


Copyright ( 2019 by the President and Fellows of Harvard College All rights reserved

Printed in the United States of America

First printing

9780674242487 (EPUB)

9780674242494 (MOBI)

9780674242470 (PDF)

CIP data for this book is available from the Library of Congress

ISBN 978-0-674-98441-7 
This book is dedicated to Katarina 
